University of Nebraska - Lincoln

DigitalCommons@University of Nebraska - Lincoln

\title{
A Complete Species Census and Evidence for Regional Declines in Piping Plovers
}

\author{
Susan M. Haig \\ USGS, Susan_Haig@usgs.gov \\ Cheron L. Ferland \\ Oregon State University \\ Francesca J. Cuthbert \\ University of Minnesota - Twin Cities \\ Jack Dingledine \\ U.S. Fish and Wildlife Service \\ J. Paul Goossen \\ Canadian Wildlife Service
}

See next page for additional authors

Follow this and additional works at: https://digitalcommons.unl.edu/usgsstaffpub

Haig, Susan M.; Ferland, Cheron L.; Cuthbert, Francesca J.; Dingledine, Jack; Goossen, J. Paul; Hecht, Anne; and McPhillips, Nell, "A Complete Species Census and Evidence for Regional Declines in Piping Plovers" (2005). USGS Staff -- Published Research. 683.

https://digitalcommons.unl.edu/usgsstaffpub/683

This Article is brought to you for free and open access by the US Geological Survey at DigitalCommons@University of Nebraska - Lincoln. It has been accepted for inclusion in USGS Staff -- Published Research by an authorized administrator of DigitalCommons@University of Nebraska - Lincoln. 


\section{Authors}

Susan M. Haig, Cheron L. Ferland, Francesca J. Cuthbert, Jack Dingledine, J. Paul Goossen, Anne Hecht, and Nell McPhillips

This article is available at DigitalCommons@University of Nebraska - Lincoln: https://digitalcommons.unl.edu/ 


\title{
A COMPLETE SPECIES CENSUS AND EVIDENCE FOR REGIONAL DECLINES IN PIPING PLOVERS
}

SUSAN M. HAIG, ${ }^{1}$ USGS Forest and Rangeland Ecosystem Science Center, 3200 SW Jefferson Way, Corvallis, OR 97331, USA CHERON L. FERLAND, ${ }^{2}$ USGS Forest and Rangeland Ecosystem Science Center, 3200 SW Jefferson Way, Corvallis, OR 97331, USA

FRANCESCA J. CUTHBERT, ${ }^{3}$ Department of Fisheries and Wildlife, University of Minnesota, 1980 Folwell Avenue, St. Paul, MN 55108, USA

JACK DINGLEDINE, U.S. Fish and Wildlife Service, 2651 Coolidge Road., East Lansing, MI 48823, USA

J. PAUL GOOSSEN, Canadian Wildlife Service, 4999 98th Avenue, Edmonton, Alberta T6B 2X3, Canada

ANNE HECHT, U.S. Fish and Wildlife Service, Weir Hill Road, Sudbury, MA 01776, USA

NELL MCPHILLIPS, ${ }^{4}$ U.S. Fish and Wildlife Service, 420 South Garfield Avenue, Suite 400, Pierre, SD 57501-5408, USA

\begin{abstract}
Complete population estimates for widely distributed species are rarely possible. However, for the third time in 10 years, an International Piping Plover (Charadrius melodus) Breeding and Winter Census was conducted throughout the species range in 2001. Nearly 1,400 participants from 32 U.S. states and Puerto Rico; 9 Canadian provinces; St. Pierre and Miquelon, France; Cuba; and the Bahamas visited 2,244 sites covering 11,836 km of shoreline habitat. During the winter census, 2,389 piping plovers were observed at $33.5 \%$ of potentially occupied sites $(n$ $=352$ ). Of these, $56.8 \%$ had $\leq 10$ birds present. The breeding census recorded 5,945 adults at 777 of 1,892 sites surveyed. More than $80 \%$ of sites with piping plovers present had $\leq 10$ birds. Results indicated an $8.4 \%$ increase from 1991 but only a $0.2 \%$ increase since 1996. Regional trends suggest that since 1991, number of breeding birds increased on the Atlantic Coast by $78 \%$ (2,920 birds; $12.4 \%$ increase since 1996) and by $80 \%$ in the Great Lakes (72 birds; 50\% increase since 1996). However, plovers declined 15\% (2,953 birds; 10\% decline since 1996) in Prairie Canada/U.S. northern Great Plains. Subregional trends since 1991 reflect a 32.4\% decline in Prairie Canada (972 birds; $42.4 \%$ decline since 1996), a $2.5 \%$ decline in the U.S. northern Great Plains (1,981 birds; $24 \%$ increase since 1996), 5.5\% decline in eastern Canada (481 birds; $14 \%$ increase since 1996), although a $66.2 \%$ increase on the U.S. Atlantic Coast (2,430 birds; $12 \%$ since 1996). While numbers were down in much of the U.S. northern Great Plains since 1996, an increase (460\%, 1,048 birds; 67.7\% increase since 1991) was detected on the Missouri River. Results from 3 complete species census efforts provide essential data for conservation planning and assessment and illustrate the utility of global censuses for species of concern.
\end{abstract}

JOURNAL OF WILDLIFE MANAGEMENT 69(1):160-173; 2005

Key words: Charadrius melodus, endangered species, North America, piping plover, population status, shorebird.

Although simple in concept, censusing an entire species is rarely undertaken. For most species, this type of assessment is nearly impossible because of vast distributions, difficulties in observing all individuals, and lack of administrative and logistical support. When undertaken, species-wide censuses are typically carried out on species with a limited distribution and during 1 phase of the annual cycle (e.g., Arlettaz 1990, Arlettaz et al. 1991 cited in Simberloff 1994, Mayfield 1992, Lewis 1995). Conversely, indices of distribution and abundance for wide-ranging species often are used (e.g., point counts for Neotropical migrant passerine birds, Robbins et al. 1986; aerial surveys for waterfowl, Cowardin

\footnotetext{
${ }^{1}$ E-mail: susan_haig@usgs.gov

2 Present address: Department of Fisheries and Wildlife, Oregon State University, Corvallis, OR 97331, USA.

${ }^{3}$ Last 5 authors listed alphabetically.

${ }^{4}$ Present address: Bureau of Reclamation, P.O. Box 1017, Bismarck, ND 58502, USA.
}

and Blohm 1992). Although these indices provide useful information, problems associated with sampling can lead to spurious results (Anderson 2001). Thus, the benefits of directly assessing distribution and abundance of an entire species over time can be significant because trends can be calculated at any scale. Initiating these assessments before a species reaches low population levels only increases their chance of recovery as factors contributing to declines can be diagnosed and addressed.

One benefit of collecting comprehensive data is the opportunity to monitor the most vulnerable populations that might otherwise go untracked. The largest populations of a species often are tracked while smaller populations on the verge of extinction can go unnoticed. While small populations may go extinct periodically (Hanski and Gilpin 1997), steady loss of a number of apparently insignificant populations can negatively affect overall (meta) population viability as the Allee effect begins to take a toll (Allee 
1931, 1951; Allee et al. 1949; Courchamp et al. 1999; Stephens and Sutherland 1999). Tracking these populations and assessing current and future viability is even more difficult for species that occupy ephemeral habitats where local extinctions of small populations can be fairly common.

For almost 20 years, intense efforts have been focused on recovery of the threatened and endangered piping plover. This species is endemic to North America and consists of 2 subspecies (American Ornithologists Union 1957; Haig et al. in preparation). Charadrius melodus melodus inhabits Atlantic Coast beaches in Canada and the United States. C. m. circumcinctus occurs on a diversity of beach-type habitats in the Great Lakes and west to Alberta and Colorado. Birds winter along U.S. Atlantic and Gulf Coast beaches and sandflats as well as parts of eastern Mexico, the Bahamas, Cuba, and the Caribbean (Haig and Elliott-Smith 2004).

Piping plovers are 1 of 50 North American breeding shorebird species and are the only extant shorebird listed as an entire species under the U.S. Endangered Species Act (http://endangered.fws.gov/wildlife.html\#Species). It is 1 of 3 extant shorebirds listed in Canada (COSEWIC 2003). Species viability is threatened due to housing and recreation development, disturbance of their ephemeral beach habitat, nest flooding, predation caused by increased human activities, and water management policies on rivers, lakes, and reservoirs (U.S. Fish and Wildlife Service 1988, 1996; Goossen et al. 2002; Haig and Elliott-Smith 2004). Listed as endangered in Canada (Haig 1985) and the U.S. Great Lakes, and threatened throughout the rest of its United States range (50 Code of Federal Regulations, part 17), current recovery efforts are facilitated through the International Piping Plover Coordination Group (IPPCG). This group consists of representatives from throughout the species breeding and winter range and has facilitated a range-wide census and habitat characterization of the species across all known suitable breeding and winter habitat in 1991, 1996, and 2001. Its goal is to monitor progress toward recovery goals and to determine and monitor changes in species distribution.

The first International Piping Plover Census in 1991 focused on determining the species distribution, particularly in the breeding season (Haig and Plissner 1993). The second census was conducted in 1996 and focused on improved delineation of the winter distribution as well as acquistion of breeding population estimates for viability modeling (Plissner and Haig 2000a,b; Mabee et al. 2001). Thus, we report results of the 2001 census and describe long-term changes in population numbers and the species breeding distribution.

\section{METHODS}

The 2001 International Piping Plover Census was conducted following the methodologies of the 1991 and 1996 censuses (Haig and Plissner 1993, Plissner and Haig 2000b) and was coordinated through a census coordinator (C. L. Ferland) and the IPPCG (S. Haig, D. Amirault, F. Cuthbert, J. Dingledine, P. Goossen, A. Hecht, N. McPhillips). Census coordinators were designated for all states, provinces, territories, and countries where piping plovers were known or presumed to breed or winter.

Censuses were conducted during 2 periods, corresponding to mid-winter and mid-breeding seasons. Multiple-counts of individuals were minimized by limiting survey efforts to a narrow time period when migratory and post-breeding movements were least likely. Double-counting appears to be minimal because no banded birds ( $n=26$ observed during census) have been observed at any 2 sites during the same census period. The winter census was conducted prior to the breeding census to allow intra-year comparisons without the confounding effects of young birds of the year. That is, if the winter census was carried out after the breeding census, results would be biased because first-year birds would be counted in winter but not in summer because they would have been eggs or chicks. The primary period for the winter census was 29 January through 12 February 2001. The breeding census was conducted from 3 to 16 June 2001 for all regions except the U.S. Atlantic, which was completed from 26 May through 3 June. The U.S. Atlantic window ensured that extreme high tides on 4 June did not cause a misrepresentation of piping plover breeding pairs. A few surveys (5 or less) completed during the weeks immediately prior to or following census windows were accepted if it was unlikely that birds were counted elsewhere.

Priorities for census coverage included all sites known to have supported piping plovers during or since the 1996 census and areas known to have suitable habitat in 1996 (Plissner and Haig 1997) or later. Observers were provided with standardized census guidelines and data forms and asked to conduct a single count of adult piping plovers. Observers were discouraged from counting during extreme weather conditions, disturbing birds, 
and searching for nests and young. Observers recorded the areas surveyed on maps to facilitate identification of specific locations of piping plovers within a site. Sites were not uniformly defined and represented 0.1-197 km of shoreline. However, as site names have been the same for all international censuses, equivalent assessments were made across years. Additional information was requested on census time, weather and tidal conditions, general habitat characteristics, extent of area censused, and identification of banded individuals.

We conducted the winter census along beaches, islands, and bays on the southeast Atlantic and Gulf coasts of the United States, Puerto Rico, and Cuba. Requests for reports of piping plover sightings also were sent to key individuals in the Bahamas, Bermuda, Jamaica, Dominican Republic, French West Indies, and Mexico.

The breeding census covered known and potential breeding areas along the Atlantic Coast from Newfoundland to South Carolina, shorelines of the Great Lakes, Lake-of-the-Woods in Minnesota and Ontario, as well as lakes, wetlands, and rivers of the northern Great Plains. Surveys were also conducted along Great Lake shorelines in Ohio, Illinois, Indiana, Pennsylvania, and New York, focusing on sites within the historic range of the Great Lakes breeding population (U.S. Fish and Wildlife Service 1988b).

We defined breeding pairs according to Plissner and Haig (2000b). Unpaired birds were separated into those seen with nests or young and others. As in previous censuses, the number of paired birds

Table 1. Wintering piping plovers (PIPL) recorded and winter survey effort in 2001 .

\begin{tabular}{lrrrrrl}
\hline State/Country & PIPL & $\begin{array}{c}\text { \% of } \\
\text { census }\end{array}$ & $\begin{array}{c}\text { Sites } \\
\text { surveyed }\end{array}$ & $\begin{array}{c}\text { Km } \\
\text { surveyed }\end{array}$ & Participants & Coordinator \\
\hline North Carolina & 87 & 3.6 & 39 & 330 & 43 & D. Allen \\
South Carolina & 78 & 3.3 & 32 & 146 & 5 & T. Murphy \\
Georgia & 111 & 4.6 & 16 & 155 & 71 & B. Winn \\
Florida & 416 & 17.4 & 122 & 900 & 162 & P. Kelly/B. Brooks \\
Atlantic & 111 & 4.6 & 34 & 242 & n/a & \\
Gulf & 305 & 12.8 & 88 & 658 & n/a & \\
Alabama & 30 & 1.3 & 13 & 47 & 10 & R. Clay \\
Mississippi & 18 & 0.8 & 12 & 167 & 9 & M. Woodrey \\
Louisiana & 511 & 21.4 & 26 & 202 & 23 & S. Shively \\
Texas & 1,042 & 43.6 & 50 & 1,075 & 53 & P. Glass/R. Cobb/ \\
& & & & & & J. Rupert \\
Puerto Rico & 6 & 0.3 & 5 & 15 & 3 & S. Earsom \\
Cuba & 55 & 2.3 & 29 & 105 & 8 & F. Shaffer \\
Bahamas & 35 & 1.5 & 8 & $n . r^{\mathrm{c}}$ & n.r. ${ }^{\mathrm{c}}$ & none \\
Total & 2,389 & $\mathrm{n} / \mathrm{a}^{\mathrm{b}}$ & 352 & 3,142 & 387 & \\
\hline
\end{tabular}

\footnotetext{
a Numbers reported are minimum estimates as not all observers recorded this information.

b $\mathrm{n} / \mathrm{a}=$ Not applicable.

c n.r. $=$ Not reported.
}

were combined with the number of individuals seen with nests or young to derive numbers of breeding pairs (U.S. Fish and Wildlife Service 1996).

We summarized winter data by state or country. Breeding data were summarized by country, state/province, and geographic region (Atlantic, Great Lakes, northern Great Plains/Prairies). Results of the 2001 census were compared with data from the 1996 and 1991 international censuses. These comparisons reflect some minor corrections to the 1991 and 1996 census results discovered as this paper was prepared. Population increases and declines are reported as simple percents and interpreted relative to their biological significance rather than using procedures such as power analyses (Reed and Blaustein 1997).

\section{RESULTS}

The 2001 International Piping Plover Census resulted from the efforts of over 1,364 biologists and volunteers from 32 U.S. states and Puerto Rico; 9 Canadian provinces; St. Pierre and Miquelon, France; Cuba; and the Bahamas, who spent more than 5,800 hours at approximately 2,244 sites surveying more than $11,836 \mathrm{~km}$ of shoreline habitat during census periods in January-February and May-June 2001. Raw data and maps from the census can be found in Ferland and Haig (2002).

\section{Winter Census}

During the winter portion of the international census, over 387 observers covered 352 sites along more than $3,142 \mathrm{~km}$ of U.S. Atlantic and Gulf coasts, northern Cuba, Puerto Rico, and the Bahamas (Table 1). All major sites were censused in the United States and Puerto Rico with the exception of the Chandeleur Islands in Louisiana, USA. Of sites surveyed, $33.5 \% \quad(n=$ 118) contained piping plovers. Most sites with piping plovers (56.8\%) contained 1-10 birds, $35.6 \%$ of plover sites had 11-50 birds, and less than $8 \%$ of plover sites had more than 50 birds. Among sites used by win- 


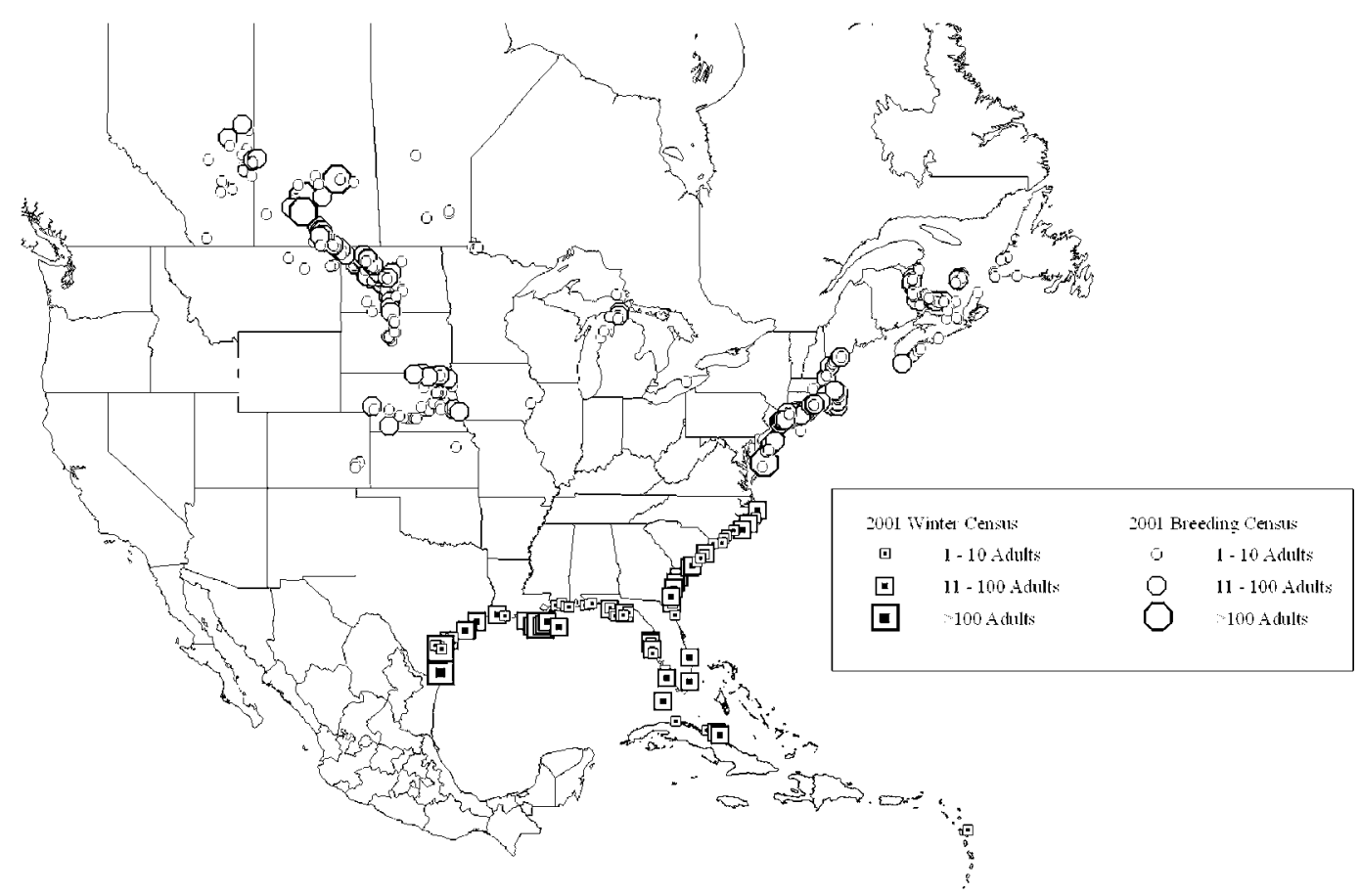

Fig. 1. Breeding and winter distribution and abundance of piping plovers in 2001. Breeding birds recorded in Canada, the United States, and St. Pierre and Miquelon, France; winter birds recorded in the southern United States, Gulf Coast of Mexico, Cuba, the Bahamas, and Caribbean.

tering piping plovers, $73.4 \%$ were found on islands, $15.8 \%$ were found on the mainland, $7.1 \%$ were found on sandbars, and the remaining birds were unspecified. When habitats were specified within sites, $36.3 \%$ of birds were seen on mudflats, $33.2 \%$ on sandy beaches, $23.1 \%$ on sand/salt flats, $2.8 \%$ on algal mats, $1 \%$ on oyster reefs, and $0.1 \%$ on gravel shores.

Overall, we located 2,389 wintering piping plovers (Table 1, Fig. 1), representing $40.2 \%$ of birds detected during the breeding census ( $n=$ $5,945)$. Most (43.6\%) were found in Texas, USA. In fact, $25.2 \%$ of all birds observed in the winter census were found on South Padre Island (Cameron County), Texas. Comparison among results from the 3 international winter censuses illustrates where survey efforts have changed over time, but it is not an effective indication of population trends because a large portion (35-60\%) of the overall breeding population is not accounted for in the winter census (Table 2).

Winter recoveries of birds banded in previous summers $(n=26)$ demonstrate that piping plovers from the same breeding sites, as well as different regions, occur at the same winter locations. For example, birds banded in Michigan were observed in North Carolina (1), South Carolina (2), Georgia (6), and the Gulf and Atlantic coasts of Florida (7; J. Stucker, F. Cuthbert, personal communication). Single birds from Newfoundland and Nova Scotia (D. Amirault, per-

Table 2. International Piping Plover Winter Census results for 1991, 1996, and 2001, and percentage of birds counted relative to subsequent international breeding censuses.

\begin{tabular}{lrrr}
\hline & \multicolumn{3}{c}{ Piping plovers } \\
\cline { 2 - 4 } State/Country & 1991 & 1996 & 2001 \\
\hline North Carolina & 20 & 50 & 87 \\
South Carolina & 51 & 78 & 78 \\
Georgia & 37 & 124 & 111 \\
Florida & 551 & 375 & 416 \\
Atlantic & 70 & 31 & 111 \\
Gulf & 481 & 44 & 305 \\
Alabama & 12 & 31 & 30 \\
Mississippi & 59 & 27 & 18 \\
Louisiana & 750 & 398 & 511 \\
Texas & 1,904 & 1,333 & 1,042 \\
Puerto Rico & 0 & 0 & 6 \\
Mexico & 27 & 16 & $\mathrm{n} . \mathrm{s}^{\mathrm{a}}$ \\
Cuba & 11 & 66 & 55 \\
Bahamas & 29 & 17 & 35 \\
Grand total & 3,451 & 2,515 & 2,389 \\
\% of Breeding Census & 62.9 & 42.4 & 40.2 \\
\hline
\end{tabular}

a n.s. = not surveyed. 
sonal communication) also were seen on the Atlantic Coast of Florida at the same site (Little Talbot Island State Park) as 3 of the birds from Michigan. One South Dakota bird (R. Niver, personal communication) was seen on the Gulf Coast of Florida at the same site (Big Marco Pass Shoal) as 1 of the Michigan birds. Three birds from Québec were seen in South Carolina, 2 of 3 at the same location (Huntington Beach, South Carolina; P. Laporte and F. Shaffer, personal communication). One Québec bird was observed in Cuba (P. Laporte and F. Shaffer, personal communication).

\section{Breeding Census}

The 2001 International Piping Plover Breeding Census was carried out over more than 4,388 hours by nearly 1,000 observers across more than 2,098 $\mathrm{km}$ of Atlantic coastline, $361 \mathrm{~km}$ of Great Lakes shore, $174 \mathrm{~km}$ of Missouri River habitat, and 5,887 additional $\mathrm{km}$ of freshwater lakes, smaller rivers, and wetlands in the Prairies and northern Great Plains (Table 3, Fig. 1). Adults were present on $41.1 \%$ of sites $(n=1,892)$ surveyed. Breeding sites were primarily characterized by low numbers: $80.7 \%$ had less than 11 birds, $18 \%$ had $11-50$ birds, and less than $2 \%$ had more than 50 piping plovers.

During the census period, 5,945 adult piping plovers, including an estimated 2,747 breeding pairs, were observed in 21 of 26 U.S. states surveyed, 9 Canadian provinces, and on St. Pierre and Miquelon, France (Table 3). Overall abundance of piping plovers has increased $8.4 \%$ since 1991 but only $0.2 \%$ since 1996 (Table 4). The distribution of piping plovers shifted since 1991 with the U.S. Atlantic Coast comprising an increasingly greater portion of the species abundance as birds recover in that region and decline in the northern Great Plains/Prairie region (Fig. 2).

Prairie Canada/U.S. Northern Great Plains.-In this region, birds (subspecies C. m. circumcinctus) were found on alkali lakes $(34.3 \%)$, reservoirs $(31.3 \%)$, rivers $(19.7 \%)$, freshwater lakes $(7.6 \%)$, dry alkali lakes $(2.4 \%)$, sandpits $(2.3 \%)$, industrial ponds $(0.4 \%)$, and gravel mines $(0.1 \%)$. Results indicate that the greatest regional decrease and local increase occurred within this region (Table 4). The decline in piping plovers in Prairie Canada ranged from $32.4 \%$ since 1991 to 42.4\% since 1996. Every western Canadian province experienced a substantial decline since 1991 and 1996. Conversely, numbers on the U.S. northern Great Plains declined 2.5\% since 1991 but increased $23.9 \%$ since 1996 . The increase is attributed to extremely high numbers on the Mis- souri River in Montana, North Dakota, South Dakota, and Nebraska. Piping plovers declined in most other parts of the northern Great Plains. For example, populations declined in western Montana; Lake of the Woods, Minnesota; and edges of the northern Great Plains. When Missouri River numbers are subtracted from totals in North Dakota, birds declined on the alkali lakes by $31.5 \%$ over the past 5 years; they declined 46.6\% since 1991 .

Great Lakes.-Piping plovers have almost doubled their numbers along the Great Lakes since 1991 (Table 4). This increase occurred primarily in northern Michigan, although a small number of birds has recolonized in northern Wisconsin on Lake Superior, in eastern Wisconsin on Lake Michigan, and 1 bird was observed in southern Ontario on Lake Erie. Two birds banded in Michigan dispersed to Wisconsin to breed (F. Cuthbert and J. Stucker, personal communication). Piping plovers were not seen in their former Great Lakes range on the New York side of Lake Ontario, Lake Erie (Ohio), Lake Huron (Michigan), or southern and western Lake Michigan (Indiana, Illinois). Great Lakes birds occurred primarily on mainland lakeshores $(61.3 \%)$ and in substrates of sand $(54.5 \%)$, mud $(23.2 \%)$, gravel $(8.0 \%)$, or vegetation $(6.2 \%)$.

Atlantic Coast.-Overall, the Atlantic population (i.e., subspecies C. m. melodus) has increased by $77.5 \%$ since 1991 and $12.4 \%$ since 1996 (Table 4). This increase primarily occurred in the United States, as eastern Canada numbers are down 5.5\% since 1991 and only increased 14\% since 1996. In the United States, piping plovers increased $66.2 \%$ since 1991 and $12.0 \%$ since 1996. Much of this increase occurred in New York and Massachusetts. These states harbor a large percent of Atlantic Coast birds and are areas where bird numbers have nearly doubled and tripled, respectively, over the past 10 years. Similar percent increases have occurred in Maine and Rhode Island, although progress since 1996 has not been as good. Conversely, piping plovers declined in North Carolina at the southern end of the species range. Across the region, birds were primarily seen on barrier islands $(39.2 \%)$, ocean fronts $(37.1 \%)$, and bays $(11.6 \%)$ but also occurred on sand bars $(2.2 \%)$, spoil islands $(1.4 \%)$, tidal creeks/marshes $(1.2 \%)$, peninsulas $(1.0 \%)$, reservoirs $(0.2 \%)$, a brackish lake $(0.1 \%)$, rivers $(0.1 \%)$, and industrial ponds $(<0.1 \%)$.

\section{DISCUSSION}

Piping plovers are a widespread species for which we have long-term, multi-scale data on 
Table 3. Piping plovers recorded and census effort for the 2001 international piping plover breeding census.

\begin{tabular}{|c|c|c|c|c|c|c|c|c|}
\hline State/Province & Adults & $\begin{array}{c}\% \text { of } \\
\text { census }\end{array}$ & $\begin{array}{l}\% \text { of } \\
\text { region }\end{array}$ & Pairs & Sites $^{a}$ & $\mathrm{Km}^{\mathrm{b}}$ & Observers ${ }^{b}$ & Coordinator(s) \\
\hline \multicolumn{9}{|l|}{ Prairie Canada and } \\
\hline U.S. Northern Great Plains & 2,953 & 49.7 & $\mathrm{n} / \mathrm{ac}$ & 1,291 & 958 & 6,235 & 414 & \\
\hline Prairie Canada & 972 & 16.3 & 32.9 & 392 & 424 & 3,506 & 240 & \\
\hline Alberta & 150 & 2.5 & 5.1 & 72 & 115 & 905 & 66 & D. Prescott \\
\hline Saskatchewan & 805 & 13.5 & 27.3 & 313 & 282 & 2,552 & 165 & L. Dunlop \\
\hline Manitoba & 16 & 0.3 & 0.5 & 7 & 23 & 37 & 7 & K. De Smet \\
\hline Ontario (Lake of Woods) & 1 & 0.0 & 0.0 & 0 & 4 & 12 & 2 & L. Heyens/S.Jones \\
\hline U.S. Northern Great Plains & 1,981 & 33.3 & 67.1 & 899 & 534 & 2,729 & 174 & \\
\hline Minnesota (Lake of Woods) & 7 & 0.1 & 0.2 & 3 & 4 & 10 & 2 & K. Haws \\
\hline Montana & 137 & 2.3 & 4.6 & 57 & 64 & 431 & 21 & L. Hanebury \\
\hline Missouri River & $7^{d}$ & $\mathrm{n} / \mathrm{a}^{\mathrm{c}}$ & $\mathrm{n} / \mathrm{a}^{\mathrm{c}}$ & $3^{d}$ & $3^{d}$ & $1^{d}$ & $n / a^{c}$ & \\
\hline North Dakota & 1,112 & 18.7 & 37.7 & 522 & 246 & 902 & 51 & K. Kreil \\
\hline Missouri River & $643^{d}$ & $\mathrm{n} / \mathrm{a}^{\mathrm{c}}$ & $\mathrm{n} / \mathrm{a}^{\mathrm{c}}$ & $298^{d}$ & $116^{d}$ & $36^{d}$ & $\mathrm{n} / \mathrm{a}^{\mathrm{c}}$ & \\
\hline South Dakota & 390 & 6.6 & 13.2 & 172 & 77 & 178 & 22 & N. McPhillips \\
\hline Missouri River & $390^{d}$ & $\mathrm{n} / \mathrm{a}^{\mathrm{c}}$ & $\mathrm{n} / \mathrm{a}^{\mathrm{c}}$ & $172^{\mathrm{d}}$ & $67^{d}$ & $136^{d}$ & $\mathrm{n} / \mathrm{a}^{\mathrm{c}}$ & \\
\hline Nebraska & 308 & 5.2 & 10.4 & 133 & 117 & 1,081 & 44 & J. Dinan \\
\hline Missouri River & $8^{d}$ & $\mathrm{n} / \mathrm{a}^{\mathrm{c}}$ & $\mathrm{n} / \mathrm{a}^{\mathrm{c}}$ & $3^{d}$ & $3^{d}$ & $1^{\mathrm{d}}$ & $n / a^{c}$ & \\
\hline Missouri River: MT, ND, SD & $1,048^{d}$ & $17.6^{\mathrm{d}}$ & $35.5^{d}$ & $476^{d}$ & $189^{d}$ & $174^{d}$ & 28 & C. Kruse/G. Pavelka \\
\hline lowa & 11 & 0.2 & 0.4 & 5 & 2 & 2 & 2 & D. Howell \\
\hline Kansas & 3 & 0.1 & 0.1 & 2 & 1 & 2 & 3 & D. Mulhern \\
\hline Colorado & 13 & 0.2 & 0.4 & 5 & 23 & 123 & 1 & J.Yost/D. Nelson \\
\hline Great Lakes & 72 & 1.2 & $n / a^{c}$ & 29 & 108 & 361 & 71 & \\
\hline Canada (Ontario) & 1 & 0.0 & 1.4 & 0 & 33 & 114 & 18 & L. Heyens/S.Jones \\
\hline United States & 71 & 1.2 & 98.6 & 29 & 75 & 247 & 53 & J. Dingledine \\
\hline Michigan & 65 & 1.1 & 90.3 & 27 & 58 & 166 & 24 & F. Cuthbert \\
\hline Wisconsin & 6 & 0.1 & 8.3 & 2 & 8 & 29 & 16 & J. Trick \\
\hline IL/IN/OH/PA/NY & 0 & 0.0 & 0.0 & 0 & 9 & 52 & 13 & J. Dingledine \\
\hline Atlantic & 2,920 & 49.1 & $n / a^{c}$ & 1,427 & 826 & 2,098 & 492 & \\
\hline St. Pierre and Miquelon France & 9 & 0.2 & 0.3 & 4 & 4 & 20 & 3 & R. Etcheberry \\
\hline Eastern Canada & 481 & 8.1 & 16.5 & 240 & 350 & 936 & 206 & \\
\hline Newfoundland & 39 & 0.7 & 1.3 & 23 & 39 & 73 & 26 & J. Brazil \\
\hline Quebec & 70 & 1.2 & 2.4 & 35 & 40 & 213 & 39 & F. Shaffer \\
\hline Prince Edward Island & 112 & 1.9 & 3.8 & 54 & 87 & 188 & 59 & J. Waddell \\
\hline New Brunswick & 167 & 2.8 & 5.7 & 83 & 66 & 303 & 39 & D. Amirault \\
\hline Nova Scotia & 93 & 1.6 & 3.2 & 45 & 118 & 159 & 43 & P. Mills/A. Bond \\
\hline U.S. Atlantic & 2,430 & 40.9 & 83.2 & 1,183 & 472 & 1,142 & 283 & \\
\hline Maine & 96 & 1.6 & 3.3 & 48 & 32 & 48 & 19 & J. Jones \\
\hline New Hampshire & 14 & 0.2 & 0.5 & 7 & 2 & 2 & 5 & C. Dudley \\
\hline Massachusetts & 962 & 16.2 & 32.9 & 481 & 161 & n.r.e & 105 & S. Melvin \\
\hline Rhode Island & 93 & 1.6 & 3.2 & 46 & 19 & 28 & 7 & C. Raithel \\
\hline Connecticut & 45 & 0.8 & 1.5 & 23 & 27 & 25 & 6 & J. Victoria \\
\hline New York & 624 & 10.5 & 21.4 & 309 & 119 & 311 & 29 & M. Gibbons \\
\hline New Jersey & 228 & 3.8 & 7.8 & 109 & 44 & 127 & 36 & D. Jenkins/T.Pover \\
\hline Delaware & 10 & 0.2 & 0.3 & 5 & 13 & 34 & 2 & A. Doolittle \\
\hline Maryland & 112 & 1.9 & 3.8 & 28 & 3 & 46 & 10 & D. Brinker \\
\hline Virginia & 198 & 3.3 & 6.8 & 106 & 23 & 194 & 26 & R. Boettcher \\
\hline North Carolina & 48 & 0.8 & 1.6 & 21 & 28 & 327 & 37 & D. Allen \\
\hline South Carolina & 0 & 0.0 & 0.0 & 0 & 1 & n.r. ${ }^{e}$ & 1 & T. Murphy \\
\hline \multicolumn{9}{|l|}{ Totals } \\
\hline United States & 4,482 & 75.4 & $\mathrm{n} / \mathrm{ac}$ & 2,111 & 1,081 & 4,118 & 510 & \\
\hline Canada & 1,454 & 24.5 & $\mathrm{n} / \mathrm{ac}$ & 632 & 807 & 4,556 & 464 & \\
\hline France & 9 & 0.2 & $\mathrm{n} / \mathrm{ac}$ & 4 & 4 & 20 & 3 & \\
\hline Grand total & 5,945 & $\mathrm{n} / \mathrm{ac}$ & $\mathrm{n} / \mathrm{ac}$ & 2,747 & 1,892 & 8,694 & 977 & \\
\hline
\end{tabular}

\footnotetext{
a 52 additional sites were not officially ground surveyed due to lack of habitat and/or access.

b Numbers reported serve as minimum estimates. Not all observers included this information.

${ }^{c} \mathrm{n} / \mathrm{a}=$ not applicable.

d Subtotals for reference only. Missouri River results by state are included in state results.

e n.r. = not reported.
} 
Table 4. Adult piping plovers recorded in the 1991, 1996, and 2001 international piping plover breeding censuses.

\begin{tabular}{|c|c|c|c|c|c|}
\hline \multirow[b]{2}{*}{ State/Province } & \multicolumn{3}{|c|}{ Adults } & \multirow{2}{*}{$\begin{array}{c}\% \text { change } \\
(1991-2001)\end{array}$} & \multirow{2}{*}{$\begin{array}{c}\text { \% change } \\
(1996-2001)\end{array}$} \\
\hline & 1991 & 1996 & 2001 & & \\
\hline Northern Great Plains/Prairies & 3,469 & 3,286 & 2,953 & -14.9 & -10.1 \\
\hline Prairie Canada & 1,437 & 1,687 & 972 & -32.4 & -42.4 \\
\hline Alberta & 180 & 276 & 150 & -16.7 & -45.7 \\
\hline Saskatchewan & 1,172 & 1,348 & 805 & -31.3 & -40.3 \\
\hline Manitoba & 80 & 60 & 16 & -80.0 & -73.3 \\
\hline Ontario & 5 & 3 & 1 & -80.0 & -66.7 \\
\hline U.S. Northern Great Plains & 2,032 & 1,599 & 1,981 & -2.5 & 23.9 \\
\hline Minnesota & 13 & 10 & 7 & -46.2 & -30.0 \\
\hline Montana & 308 & 153 & 137 & -55.5 & -10.5 \\
\hline Missouri River & $26^{e}$ & $24^{e}$ & $7^{e}$ & $n / a^{b}$ & $\mathrm{n} / \mathrm{a}^{\mathrm{b}}$ \\
\hline North Dakota & 992 & 1,004 & 1,112 & 12.1 & 10.8 \\
\hline Missouri River & $307^{e}$ & $125^{\mathrm{e}}$ & $643^{e}$ & $n / a^{b}$ & $\mathrm{n} / \mathrm{a}^{\mathrm{b}}$ \\
\hline South Dakota & 295 & 29 & 390 & 32.2 & $1,244.8$ \\
\hline Missouri River & $292^{e f}$ & $29 \mathrm{eg}$ & $390^{e}$ & $n / a^{b}$ & $n / a^{b}$ \\
\hline Nebraska & 398 & 375 & 308 & -22.6 & -17.9 \\
\hline Missouri River & $0^{\mathrm{e}}$ & $9^{e}$ & $8^{\mathrm{e}}$ & $n / a^{b}$ & $\mathrm{n} / \mathrm{a}^{\mathrm{b}}$ \\
\hline Missouri River (MT, ND, SD, NE) & $625^{\mathrm{e}}$ & $187^{e}$ & $1,048^{e}$ & 67.7 & 460.4 \\
\hline lowa & 13 & 14 & 11 & -15.4 & -21.4 \\
\hline Kansas & 0 & 1 & 3 & 300.0 & 200.0 \\
\hline Colorado & 13 & 13 & 13 & 0.0 & 0.0 \\
\hline Oklahoma & 0 & n.s. ${ }^{a}$ & n.s. ${ }^{a}$ & $\mathrm{n} / \mathrm{a}^{\mathrm{b}}$ & $\mathrm{n} / \mathrm{a}^{\mathrm{b}}$ \\
\hline Great Lakes & 40 & 48 & 72 & 80.0 & 50.0 \\
\hline Canada (Ontario) & 0 & 1 & 1 & 100.0 & 0.0 \\
\hline United States & 40 & 47 & 71 & 77.5 & 51.1 \\
\hline Michigan & 39 & 47 & 65 & 66.7 & 38.3 \\
\hline Wisconsin & 1 & 0 & 6 & 500.0 & 600.0 \\
\hline $\mathrm{IL} / \mathrm{IN} / \mathrm{OH} / \mathrm{PA} / \mathrm{NY}$ & n.s. ${ }^{a}$ & n.s. ${ }^{a}$ & 0 & $n / a^{b}$ & $n / a^{b}$ \\
\hline Atlantic & 1,645 & 2,597 & 2,920 & 77.5 & 12.4 \\
\hline St. Pierre and Miquelon (France) & 4 & 6 & 9 & 125.0 & 50.0 \\
\hline Eastern Canada & 509 & 422 & 481 & -5.5 & 14.0 \\
\hline Newfoundland & 7 & 27 & 39 & 457.1 & 44.4 \\
\hline Quebec & 76 & 104 & 70 & -7.9 & -32.7 \\
\hline Prince Edward Island & 110 & 66 & 112 & 1.8 & 69.7 \\
\hline New Brunswick & 203 & 146 & 167 & -17.7 & 14.4 \\
\hline Nova Scotia & 113 & 79 & 93 & -17.7 & 17.7 \\
\hline U.S. Atlantic & 1,462 & 2,169 & 2,430 & 66.2 & 12.0 \\
\hline Maine & 38 & 114 & 96 & 152.6 & -15.8 \\
\hline New Hampshire & n.s. ${ }^{a}$ & n.s. ${ }^{a}$ & 14 & $n / a^{b}$ & $\mathrm{n} / \mathrm{a}^{\mathrm{b}}$ \\
\hline Massachusetts & 293 & 877 & 962 & 228.3 & 9.7 \\
\hline Rhode Island & 47 & 91 & 93 & 97.9 & 2.2 \\
\hline Connecticut & 67 & 42 & 45 & -32.8 & 7.1 \\
\hline New York & $334^{c}$ & 493 & 624 & 86.8 & 26.6 \\
\hline New Jersey & 280 & $225^{d}$ & 228 & -18.6 & 1.3 \\
\hline Delaware & 10 & 8 & 10 & 0.0 & 25.0 \\
\hline Maryland & 35 & 91 & 112 & 220.0 & 23.1 \\
\hline Virginia & 270 & 155 & 198 & -26.7 & 27.7 \\
\hline North Carolina & 86 & 73 & 48 & -44.2 & -34.2 \\
\hline South Carolina & 2 & 0 & 0 & -100.0 & 0.0 \\
\hline \multicolumn{6}{|l|}{ Totals } \\
\hline U.S. & 3,534 & 3,815 & 4,482 & 26.8 & 17.5 \\
\hline Canada & 1,946 & 2,110 & 1,454 & -25.3 & -31.1 \\
\hline France & 4 & 6 & 9 & 125.0 & 50.0 \\
\hline Grand total & 5,484 & 5,931 & 5,945 & 8.4 & 0.2 \\
\hline
\end{tabular}

a n.s. = not surveyed.

b $\mathrm{n} / \mathrm{a}=$ not applicable.

c Adjusted $1991 \mathrm{New}$ York tally due to previous error (originally reported as $n=338$; revised $n=334$ ).

d Adjusted 1996 New Jersey tally due to previous error (originally reported as $n=209$; revised $n=225$ ).

e Subtotals for reference only. Missouri River results by state are included in state results.

f Adjusted 1991 South Dakota tally due to previous error (originally reported as $n=290$; revised $n=292$ ).

g Adjusted 1996 South Dakota tally due to previous error (originally reported as $n=27$;revised $n=29$ ). 
changes in distribution and abundance. Results from 3 international breeding censuses illustrate that in the absence of repeated complete census efforts, it would not be possible to define and place into perspective local, regional, and species-wide trends. The census further illustrates the value of collecting simple field data over a species range. Results of

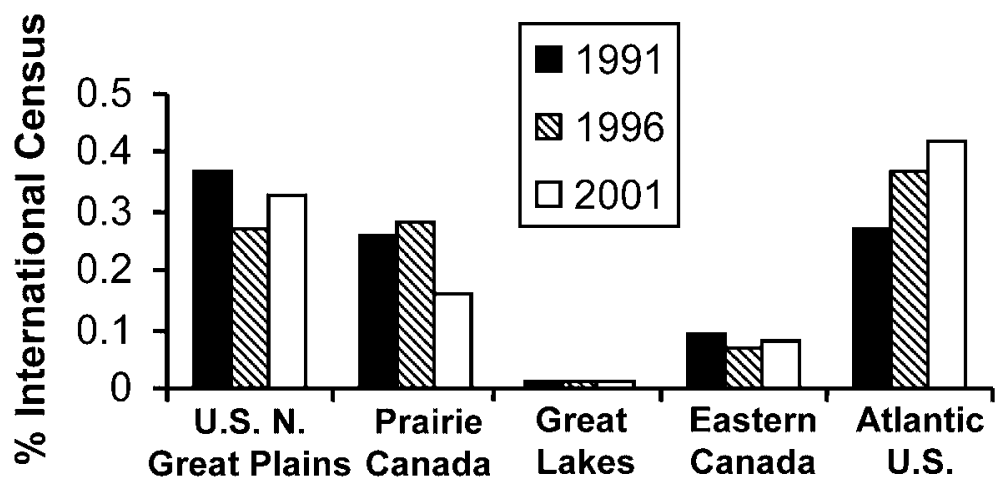
the census represent the

Fig. 2. Changes in breeding distribution and abundance in piping plovers as recorded in international censuses in 1991, 1996, and 2001.

most extensive endan-

gered species census effort in North America, the only accurate population estimate for a North American shorebird (Brown et al. 2000), the only complete widespread shorebird population estimate worldwide, and 1 of very few complete avian species population estimates worldwide.

\section{Winter Census}

The International Piping Plover Winter Census remains the most extensive winter survey for piping plovers. The results are helpful in identifying specific sites of concern and overall patterns of piping plover density and distribution across the United States in winter. The winter census is organized as a stand-alone survey each time it is carried out and therefore is not added to on-going activities as occurs with the breeding census. Thus, it requires significant effort to cover known sites in the United States, and exploration of areas outside the country is rarely possible. This is unfortunate because each International Winter Census identifies less than $65 \%$ of breeding birds, and the winter range of the species has yet to be clearly delineated. In future years, it will remain essential to try to conduct comprehensive surveys on the Laguna Madre de Tamaulipas and associated beaches in Mexico as has been attempted in the past (Haig and Oring 1985, Mabee et al. 2001). Additional surveys in Cuba, the Bahamas, and Caribbean also are a high priority. More piping plovers have been counted in Cuba as surveys were extended along the north coast (F. Shaffer and P. Laporte, personal communication) and birds have been seen in Guadalupe (A. Leveques, personal communication). However, recent shorebird surveys in the Dominican Republic and Jamaica did not record piping plovers ( $\mathrm{J}$.
Collazo, personal communication; A. Sutton, personal communication).

Because tidal conditions can significantly alter results, timing of the winter census window is important. Extremely low tides, often prevalent in Texas and other places in January, expose vast expanses of sand and mudflats that are extremely difficult to access. These areas provide habitat for most of the known wintering piping plovers, hence miscounting leads to significant error. In 2001, we moved the census window by 1 week to avoid this problem, but high winds created prolonged poor habitat conditions that made surveying difficult because birds may have moved to other (inland) habitats. In addition, weather conditions prohibited censusing of the Chandeleur Islands in Louisiana. These islands held a large number $(n=87-131)$ of piping plovers in the past (Haig and Plissner 1993, Plissner and Haig $2000 \mathrm{~b}$ ) and should be a focus of future efforts. Therefore, for several reasons, it is not possible to draw firm conclusions regarding population trends from the winter census data across years.

The winter census provided an opportunity to look for birds banded during previous breeding seasons to document connectivity of breeding populations in winter and winter site fidelity. While there are few extensive, on-going banding programs in breeding areas, results from all 3 international censuses ( $n=118$ resighted birds) as well as Haig and Oring (1988b) suggest that most Prairie and northern Great Plains birds winter in the Gulf of Mexico, and most Atlantic birds are seen further south on the Atlantic Coast or the Caribbean. Some crossing over into the Gulf or Atlantic occurs. Among 73 resights of Prairie Canada/northern Great Plains birds in winter, 4 
were seen on the Atlantic Coast, 4 were seen in the Florida Keys, and the remaining birds were seen in the Gulf of Mexico, primarily $(n=27)$ in Texas. Most birds from Michigan $(n=19)$ were observed in the Florida Keys, Georgia, South Carolina, and North Carolina, although 1 was seen in Texas and several were discovered on the Gulf coast of Florida. This pattern was substantiated by Wemmer (2000). Atlantic birds $(n=26)$ were primarily observed on the Atlantic Coast and Cuba, although 3 birds from Massachusetts were observed in Texas.

Sighting banded birds in winter helps confirm significance of specific sites and is an indication that many winter sites provide habitat to birds from different breeding populations. For example, specific sites (e.g., Bolivar, Texas; Honeymoon Island, Florida; Huntington Beach, South Carolina) tend to be used annually by piping plovers from multiple breeding regions. Recent estimates of piping plover winter space use further suggest that they have small home ranges and are site faithful (Drake et al. 2001). Together, these winter behavior patterns indicate the great importance of specific winter sites for individual plovers and suggest degradation of these areas may critically affect population recovery.

The 2001 winter census further confirms conclusions from previous international censuses that sand/mud/salt flats are a preferred habitat for wintering piping plovers. Drake et al. (2001) also found algal mats to be a preferred habitat in Texas. These ephemeral habitats often are located on the back side of barrier islands, are rich in invertebrates, and are habitats that shift size, exposure, and position with the tide and winds. Thus, great numbers of plovers can be found in different geographic locations depending on the daily availability of mud/sand/salt flats. This makes it difficult to specifically pinpoint some important sites (e.g., along Laguna Madre, Texas, USA) for protection of wintering birds. For these reasons, it is important that a network of these ephemeral habitats remain available over a broad area.

\section{Breeding Census}

Breeding census data can be viewed with confidence for numerous reasons. First, piping plovers nest in very definable and easily recognizable sites and at a relatively discreet number of sites compared to most other shorebirds or beachnesting birds. Further, throughout much of the breeding range, sites are censused at least annually, and many are monitored throughout the breeding season. For example, among sites where piping plovers are known to breed, almost all Atlantic sites; all Great Lakes sites; Lake of the Woods, Minnesota; the Missouri River; most sites in Alberta and Manitoba; Lake Diefenbaker, Saskatchewan; the Missouri Coteau area of North Dakota; and many other sites scattered throughout the Prairie Canada/northern Great Plains region are monitored annually, often by the same people. In fact, the only sites not monitored annually are smaller sites in Saskatchewan and central Manitoba. Thus, we have a high likelihood of detecting birds when the international census is carried out. While some of the large alkali lakes in Saskatchewan (e.g., Big Quill Lake and Chaplin Lake) can be difficult to cover due to the vastness of open beach habitat and mud conditions, they are always censused in the same manner. Thus, results are comparable among international censuses.

Prairie Canada/U.S. Northern Great Plains.Compared to other regions, this western portion of the species' range is characterized by a greater diversity of habitats and varying site conditions due to the dynamic nature of weather and resulting ephemerality of many sites. However, despite its vastness, it is tremendously fragile.

Prairie Canada represents the largest subregional extent of piping plover habitat, and until 2001, several sites had the highest numbers of breeding pairs in the species' range (e.g., Lake Diefenbaker, Big Quill Lake, and Chaplin Lake have always been among the top 10 most populous breeding sites). Thus, the scope of decline indicated by the 2001 results is remarkable for any avian species and raises concerns regarding piping plover viability in this region.

Reasons for decline vary by site. In many places, extensive and ongoing drought resulted in complete drying of the habitat and encroachment of vegetation. Conversely, at other sites, severe flooding destroyed nesting habitat. Furthermore, much of the habitat that appears viable does not contain birds.

Extensive habitat loss or degradation in Alberta, Saskatchewan, and Manitoba may have caused birds to seek better breeding habitat such as the unusually good habitat that has occurred in recent years on the Missouri River in the U.S. northern Great Plains. It is possible that Prairie Canada birds stopped short on their way north or assessed the northern habitat and retreated south to better conditions. In general, these piping plovers are fairly site faithful with more than 
$67 \%$ of adults returning to some sites in Manitoba (Haig and Oring 1988b). However, large-scale dispersal is possible. For example, during the 2001 census, 2 adults banded the year before in Saskatchewan were reported breeding in Colorado (D. Nelson, P. Goossen, personal communication), and a chick previously banded on the Missouri River was observed at Lake of the Woods, Minnesota (K. Hawes, personal communication). However, the number of birds that would have had to disperse to the United States to account for the decline detected in Prairie Canada would represent an unprecedented dispersal event for this species. Additionally, even if birds did shift to the south, the increase in the number of birds on the Missouri River in 2001 does not compensate for the number lost from Prairie Canada.

It is possible that due to long-term habitat loss or alteration, some local populations have become so small that they are not demographically viable and ultimately they collapse-the Allee effect (Allee 1931, 1951; see beyond). This effect has been described for piping plovers in areas in Manitoba (S. Haig, unpublished data), Michigan (Lambert and Ratcliffe 1981, Price 2002), Ontario (Lambert and Ratcliffe 1981), and possibly Minnesota (Maxson and Hawes 2000; S. Maxson, personal communication). In these cases, males established territories at sites where the population had been higher but currently was so small that they were not able to attract or retain females. Most of these events occurred at locations where the species' range was contracting.

Remedies for significant regional population decline detected in Prairie Canada are not clear. If birds did seek out better habitat on the Missouri River, some may return to Prairie Canada as Missouri River conditions start to deteriorate. This may happen soon because Missouri River habitat has already begun to change (N. McPhillips, personal communication). However, as drought conditions appear to be continuing in much of Prairie Canada, the availability of suitable habitat may continue to be a limiting factor in the region.

In the U.S. northern Great Plains, the predominant change noted in 2001 was the increase of breeding piping plovers along the Missouri River. In 1991, following a drought period that exposed shoreline habitat on Missouri River reservoirs, plover numbers on the Missouri River were at their highest since 1984 (Haig and Oring 1985). In 1996, extreme flows on the Missouri River inundated sandbars and shorelines, severely lim- iting the amount of available habitat, and few piping plovers nested. High flows in 1996 and 1997 returned the Missouri River to a more natural braided channel in riverine reaches, with thousands of hectares of islands and sandbars formed and scoured free of vegetation by floods. Plover numbers and productivity increased in subsequent years. By 2001, habitat in riverine portions was reduced by more than $50 \%$, but droughts in the upper basin caused reservoir levels to drop, creating hundreds of kilometers of potential nesting habitat. Lakes Sakakawea and Oahe, in the upper Missouri River basin, held record numbers of nesting piping plovers in 2001 .

Results from the Missouri River must be viewed in the context of the rest of the region. In addition to declines in Prairie Canada, declines occurred in all U.S. northern Great Plains states (if Missouri River sites are excluded) except Kansas and Colorado. In addition, as a result of heavy flooding, birds at Lake of the Woods, Minnesota-the closest link to the Great Lakes and Prairie Canada-were reduced to near extinction (Maxson and Hawes 2000).

Great Lakes.-Piping plover numbers have increased substantially over the past 10 years in the Great Lakes due to a combination of natural factors and intensive management (Wemmer 2000). Water levels on the western Great Lakes in 2000 and 2001 approached historic low levels and resulted in increased availability of potential piping plover habitat. At present, habitat currently does not appear to be limiting, and chicks have had ideal weather conditions for survival to fledging in recent years (e.g., above-average temperatures, below-average precipitation). There are significantly more breeding or potentially breeding adults in the Great Lakes, and the breeding range has expanded since the 1980s (Price 2002). It is unclear whether increased dispersal of birds into Wisconsin and Michigan is a result of more habitat availability or if birds within the core breeding area in Michigan have exceeded the capacity of their breeding areas and are dispersing, or both.

Intensive nest site management (e.g., use of predator exclosures, beach closures, plover monitors) and captive rearing efforts have played a large role in the population increase in Michigan (Wemmer 2000). As a consequence, productivity rates observed in 2001 were the highest recorded since annual monitoring began. While predation and human disturbance remain a threat, recent mitigation is having a positive effect on the latter. However, models (Wemmer et al. 2001) suggest 
that in order for the Great Lakes population to maintain viability and persist for 100 years, these activities, along with additional habitat protection, must be maintained for the long-term.

Atlantic Coast.-Census-wide, the greatest regional increases occurred on the Atlantic Coast; however, these were observed primarily in New England rather than region-wide. In eastern Canada, the overall increase of $14 \%$ since 1996 needs to be viewed in light of several factors. First, all provinces except Québec reported an increase in number of breeding birds in 2001 as compared to 1996, and Prince Edward Island exceeded population levels recorded in 1991. However, part of the increase can be attributed to more intensive survey effort, particularly in Newfoundland. Further, the current population level of 481 individuals is lower than the 1991 level of 509 individuals.

Distribution of piping plovers in eastern Canada has shifted within and among provinces since 1991 and partly reflects differing trends in habitat suitability among provinces. Within New Brunswick and Prince Edward Island, major flooding events and winter storms have greatly enhanced nesting habitat, and new nesting sites have been created where breeding was not known in the past. The amount of suitable habitat has been consistent in Newfoundland and Québec. In Nova Scotia, habitat at some sites has become less suitable for nesting. Substantive protection measures that promote conservation likely contributed to localized increases in all provinces. However, in all provinces some locations that appeared to be suitable did not support nesting piping plovers.

Overall population increases in the U.S. Atlantic between 1996 and 2001 masks substantial regional population dips that occurred in the intervening years (U.S. Fish and Wildlife Service 1997-2000), and a steep continuing decline at the southern end of the range.

The population in New England (Maine, New Hampshire, Massachusetts, Rhode Island, Connecticut) attained the minimum subpopulation target established in the revised Atlantic Coast Recovery Plan (U.S. Fish and Wildlife Service 1996), and high-quality habitat remained abundant. However, 2/3 of the 1996-2001 population increase occurred in the first 2 years (A. Hecht, unpublished data; http://pipingplover.fws.gov/ status/index.html). In 1997, breeding piping plovers were observed in New Hampshire after a 13-year hiatus and have since nested there consistently. Plovers also established breeding activity at new sites in Massachusetts and Rhode Island.
The 5-year net gain in New York and New Jersey obscures an 11\% decline between 1996 and 1998 (A. Hecht, unpublished data; http://pipingplover.fws.gov/status/index.html). Most of that decrease occurred in New Jersey, where it was linked with a 1996 oil spill and extremely poor productivity in 1997. In this region, historical, ongoing, and proposed development, including artificially stabilized beaches, limit the potential for natural development of optimal chick rearing habitats.

Breeding numbers in the southern part of the Atlantic range (Delaware, Maryland, Virginia, and North Carolina) remain precarious. Although bird numbers increased slightly in 1997 and 1998, they dipped below 1996 numbers in 1999 and 2000, before increasing again in 2001 (A. Hecht, unpublished data; http://pipingplover.fws.gov/status/index.html). The most recent increase is attributable largely to strong productivity and population growth on 3 northern Virginia barrier islands. By contrast, numbers in the southern half of the Virginia barrier island chain and North Carolina have experienced a steep decline, from 75 pairs in 1995 to only 25 in 2001. Piping plovers appear to have more narrow nesting habitat requirements in the southern part of their Atlantic Coast range than in New England, and availability of preferred overwash and ephemeral pool chick-rearing habitats is limited by efforts to artificially stabilize beaches and natural succession (A. Hecht, personal communication). However, the current population may not be large enough to fill available habitat. Examples of high productivity and rapid population response in Maryland (increase from 19 to 61 pairs between 1993 and 1996) and 3 northern Virginia barrier islands (1998-2001 increase from 71 to 98 pairs) indicates that substantial increases are possible.

\section{Changing Population Structure in Piping Plovers}

While demographic data are missing for many piping plover populations due to low numbers of birds banded and inadequate funding for monitoring, changes in population distribution, size, and density noted in the international censuses indicate areas of concern. For example, drought and flooding in much of the Prairie Canada/U.S. northern Great Plains region resulted in largescale loss of habitat, at least temporarily. While failure of metapopulation dynamics has not been documented as a cause for extinction in birds (Simberloff 1994), the regional decline that 
occurred in Prairie Canada/U.S. northern Great Plains may be an example of this type of failure. This could occur for a variety of reasons. First, the net loss of birds is significant. Second, breakdown in habitat connectivity across the region may also be important. Piping plovers may be more faithful to a local mosaic of sites than to a specific site. For example, $78 \%$ of adults in Manitoba that had failed nests moved to sites within $100 \mathrm{~km}$ in subsequent years (Haig and Oring $1988 a$ ). Further, chicks usually do not return to specific natal sites but often return to a local region (Haig and Oring 1988b). Thus, when local conditions decline, maintenance of nearby suitable habitat may be critical. Next, birds may have dispersed to the Missouri River but unless habitat conditions improve quickly in the rest of the region, adults that moved may not survive long enough to disperse back to their former sites. Once the tradition of using sites in this part of the region is broken, it may be more difficult for subsequent birds to invade (Keitt et al. 2001, Price 2002). Co-adapted gene complexes (Shields 1983) evolved for breeding on a prairie wetland habitat may not be beneficial on a large river system and could be lost prior to dispersal back to Prairie Canada. Moreover, as these birds have adapted to a dynamic habitat, they must be flexible to survive, although permanent changes in habitat make this more difficult.

Observers reported that some areas that were recently used for nesting were no longer used by breeding piping plovers. Across the range, most nest sites had fewer birds breeding at them. This may result from a larger loss of habitat, but could be a more local phenomenon as well. In many places in the past (e.g., Wilcox 1959) and in some currently, piping plovers breed semi-colonially. They also may co-occur with other shorebirds such as American avocets (Recurvirostra americana) and killdeer (C. vociferus; Haig and ElliottSmith 2004). Together, these birds provide added vigilance and some protection from predators. Once numbers decrease, this benefit may be diminished (although see Mayer and Ryan 1991). Courtship and mating systems may also be altered by decreasing densities of piping plovers. Male piping plovers perform an elaborate flight display and vocalizations during courtship. In Manitoba, males breeding semicolonially often performed these displays concurrently and with increased intensity as more males joined in (S. M. Haig, unpublished data). Thus, the ability to attract females to a site may be enhanced by the presence of other courting males, and a decline in density of breeding males may reduce recruitment to what otherwise might be viable nesting areas.

\section{MANAGEMENT IMPLICATIONS}

As a result of this species-wide census, we are able to provide perspective on rangewide distribution and dispersal issues throughout the annual cycle. Most obvious from census results is the need to better define piping plover winter distribution. Under-funded attempts over the past 20 years have made some head-way, but a significant effort should be launched to determine the species' distribution and threats to their habitat in Lousiana's Chandeleur Islands, Texas and Mexico's Laguna Madre, Cuba, and the Bahamas. More intensive and frequent surveys of United States wintering habitat are needed to provide a better understanding of intra- and inter-annual shifts in piping plover numbers and increase opportunities to resight birds banded during the breeding season. Additional banding may be warranted to document the extent of movements between Prairie Canada and the northern Great Plains as well as within the newly-expanding Great Lakes population.

Growing evidence that a number of breeding sites may no longer be used by piping plovers points to the significance of continuing efforts such as the international census, especially in parts of the range such as Prairie Canada and the northern Great Plains where region-wide annual surveys cannot be conducted, so that large and small sites are monitored and site-specific management can be implemented.

\section{ACKNOWLEDGMENTS}

We thank the nearly 1,400 federal, state, provincial, and nongovernmental biologists and other volunteers throughout North America whose willingness to participate was the key to success of the census. Additionally, we are grateful to R. Elliott, C. L. Gratto-Trevor, J. Kelly, P. W. Paton, and B. G. Peterjohn for comments on a previous draft of this paper. Further, we thank D. C. Kesler, P. M. Sanzenbacher, G. W. Lienkaemper, and R. W. Jacobs for advice on data management and mapping, and T. A. Goodrich for proofing data. Funding for the census was provided by the USGS Forest and Rangeland Ecosystem Science Center, U.S. Fish and Wildlife Service, U.S. Army Corps of Engineers, and the Missouri River Natural Resources Committee. 


\section{LITERATURE CITED}

Allee, W. C. 1931. Animal aggregations. University of Chicago Press, Chicago, Illinois, USA.

1951. The social life of animals. Beacon, Boston, Massachusetts, USA.

- A. E. Emerson, O. Park, T. Park, and K. P. SCHMIDT. 1949. Principles of animal ecology. Saunders, Philadelphia, Pennsylvania, USA.

AMERICAN ORNITHOLOGISTS' UnION. 1957. Checklist of North American birds. Fifth edition. American Ornithologists Union, Washington, D.C., USA.

ANDERSON, D. R. 2001. The need to get the basics right in wildlife studies. Wildlife Society Bulletin 29:1294-1297.

ArletTAZ, R. 1990. La population relictuelle du Hibou petit-duc, Otus scops, en Valais central: dynamique, organisation spatiale, habitat et protection. Bulletin de la Société Romande pour l'Etude de la Protection des Oiseaux 40:321-343. [In French.]

, Fournier, M. Julliard, A. Lugan, D. Rossel, AND A. Sierro. 1991. Origines du déclin de la population relictuelle du Hibou petit-duc, Otus scops, dans les Alpes valaisannes (sud-ouest de la Suisse): une approche empirique. Pages 15-30 in M. Julliard, editor. Rapaces nocturnes. Actes du 30e Colloque interregional d'ornithologie Porrentruy, Switzerland. [In French.]

Brown, S., C. Hickey, AND B. HARrington, editors. 2000. The U.S. shorebird conservation plan. Manomet Center for Conservation Sciences, Manomet, Massachusetts, USA.

COSEWIC. 2003. Canadian species at risk, May 2003. Committee on the Status of Endangered Species in Canada, Ottawa, Ontario, Canada.

Courchamp, F., T. Clutton-Brock, and B. Grenfell. 1999. Inverse density dependence and the Allee effect. Trends in Ecology and Evolution 14:405-410.

Cowardin, L. M., AND R. J. Blohm. 1992. Breeding population inventories and measurements of recruitment. Pages 423-445 in B. D. J. Batt, A. D. Afton, M. G. Anderson, C. D. Ankney, D. H. Johnson, J. A. Kadlec, and G. L. Krapu, editors. Ecology and management of breeding waterfowl. University of Minnesota Press, Minneapolis, USA.

Drake, K. R., J. E. Thompson, K. L. Drake, AND C. Zonick. 2001. Movements, habitat use, and survival of nonbreeding piping plovers. Condor 103:259-267.

FerLand, C. L., AND S. M. HAIG. 2002. The 2001 international piping plover and snowy plover census. Report to USGS Forest and Rangeland Ecosystem Science Center, Corvallis, Oregon, USA.

Goossen, J. P, D. L. Amirault, J. Arndt, R. Bjorge, S. Boates, J. Brazil, S. Brechtel, R. Chiasson, G. N. Corbett, R. Curley, M. Elderkin, S. P. Flemming, W. Harris, L. Heyens, D. HJertaAs, M. Huot, B. Johnson, R. Jones, W. KoOnZ, P. LAPORTE, D. MCAsKiLl, R. I. G. Morrison, S. Richard, F. Shaffer, C. Stewart, L. Swanson, AND E. WILTSE. 2002. National recovery plan for the piping plover (Charadrius melodus). National Recovery Plan Number 22. Recovery of nationally endangered wildlife. Ottawa, Ontario, Canada.

HAIG, S. M. 1985. Status of piping plovers in Canada. Report to the committee on the status of endangered wildlife in Canada (COSEWIC). Ottawa, Ontario, Canada.

-, AND E. Elliott-Smith. 2004. The piping plover (Charadrius melodus). Number 2 in A. Poole and F.
Gill, editors. The birds of North America. The Academy of Natural Sciences, Philadelphia, Pennsylvania, USA, and The American Ornithologists Union, Washington D.C., USA.

- AND L. W. ORING. 1985. The distribution and status of the piping plover throughout the annual cycle. Journal of Field Ornithology 56:334-345.

- AND —. 1988a. Mate, site, and territory fidelity in piping plovers. Auk 105:268-277.

in AND $1988 b$. Distribution and dispersal in the piping plover. Auk 105:630-638.

—, AND J. H. Plissner. 1993. Distribution and abundance of piping plovers: results and implications of the 1991 international census. Condor 95:145-156.

HANSKI, I. A., AND M. E. GILPIN, editors. 1997. Metapopulation biology: ecology, genetics, and evolution. Academic Press, New York, USA.

KeItT, T. H., M. A. Lewis, AND R. D. Holt. 2001. Allee effects, invasion pinning, and species borders. American Naturalist 157:203-216.

LAMBERT, A., AND B. RATCLIFFe. 1981. Present status of the piping plover in Michigan. Jack-Pine Warbler 59:44-52.

LEWIS, J. C. 1995. The whooping crane. Number 153 in A. Poole and F. Gill, editors. The birds of North America. The Academy of Natural Sciences, Philadelphia, Pennsylvania, USA, and The American Ornithologists Union, Washington D.C., USA.

Mabee, T., J. H. Plissner, S. M. Haig, and J. P. Goossen. 2001. Distribution of North American plovers in the Laguna Madre region of Tamaulipas, Mexico and Texas USA. Wader Study Group Bulletin 94:39-43.

Maxson, S. J., AND K. V. Hawes. 2000. Population studies of piping plovers at Lake of the Woods, Minnesota: 19 year history of a declining population. Waterbirds 23:475-481.

MAYER, P. M., AND M. R. RYAN. 1991. Survival rates of artificial piping plover nests in American avocet colonies. Condor 93:753-755.

MaYfield, H. F. 1992. The Kirtland's warbler. Number 19 in A. Poole and F. Gill, editors. The birds of North America. The Academy of Natural Sciences, Philadelphia, Pennsylvania, USA, and The American Ornithologists Union, Washington D.C., USA.

Plissner, J. H. 2000a. Metapopulation models for piping plovers. Biological Conservation 92:163-173.

$2000 \mathrm{~b}$. Status of a broadly-distributed endangered species: results and implications of the second international piping plover census. Canadian Journal of Zoology 78:1-12.

_ AND S. M. HAIG. 1997. The 1996 international piping plover census. Report to USGS Forest and Rangeland Ecosystem Science Center, Corvallis, Oregon, USA.

PRICE, E. W. 2002. Piping plover recolonization potential in the Great Lakes: assessment of historic habitat and dispersal events. Thesis, University of Minnesota, Twin Cities, USA.

REed, J. M., AND A. R. Blaustein. 1997. Biologically significant population declines and statistical power. Conservation Biology 11:281-282.

Robbins, C. S., D. BystraK, AND P. H. Geissler. 1986. The breeding bird survey: its first fifteen years. 1965-79. U.S. Fish and Wildlife Service Resource Publication No. 157.

SHIELDS, W. M. 1983. Optimal outbreeding and the evolution of philopatry. Pages 132-159 in I. R. Swingland and 
P. J. Greenwood, editors. The ecology of animal movement. Clarendon Press, Oxford, United Kingdom.

SimberlofF, D. 1994. Habitat fragmentation and population extinction of birds. Ibis 137:105-111.

Stephens, P. A., and W. J. Sutherland. 1999. Consequences of the Allee effect for behaviour, ecology, and conservation. Trends in Ecology and Evolution 14:401-405.

U.S. FiSH AND WiLdLIFE SERVICE. 1985. Endangered and threatened wildlife and plants; determination of endangered and threatened status for the piping plover, final rule. Federal Register 50(238):50726-50734.

1988a. Atlantic Coast piping plover recovery plan. U.S. Fish and Wildlife Service, Newton Corner, Massachusetts, USA.

. 1988b. Recovery plan for piping plovers breeding on the Great Lakes and northern Great Plains. U.S. Fish and Wildlife Service, Twin Cities, Minnesota, USA.
1996. Piping plover (Charadrius melodus) Atlantic Coast population revised recovery plan. U.S. Fish and Wildlife Service, Hadley, Massachusetts, USA. 1997-2000. Annual status updates, 1996-2001 U.S. Atlantic Coast piping plover population. U.S. Fish and Wildlife Service, Sudbury, Massachusetts, USA.

Wemmer, L. C. 2000. Conservation of the piping plover (Charadrius melodus) in the Great Lakes region: a landscape-ecosystem approach. Dissertation, University of Minnesota, Twin Cities, USA.

, U. Ozesmi, And F. J. Cuthbert. 2001. A habitatbased population model for the Great Lakes population of the piping plover (Charadrius melodus). Biological Conservation 99:169-181.

Wilcox, L. 1959. A twenty year banding study on the piping plover. Auk 76:129-152.

Associate Editor: Kelly. 